\title{
Challenges, Reforms and Developments in the Indian Insurance Sector
}

\author{
Dr. Ashfaque Ahmed*, Dr Syed Mohammad Akmal**, Mr. Murtadha Alhafufi***, Dr Syed \\ Mohammad Faisal****, Dr Ahmad Khalid Khan***** \\ *Associate Professor, Saudi Electronic University, Kingdom of Saudi Arabia \\ **Assistant Professor, Saudi Electronic University, Kingdom of Saudi Arabia \\ *** Lecturer, Jazan University, Kingdom of Saudi Arabia \\ ****Assistant Professor, Jazan University, Kingdom of Saudi Arabia \\ *****Assistant Professor, Jazan University, Kingdom of Saudi Arabia
}

\begin{abstract}
Purpose: The objective of this descriptive paper is to elaborate and examine how an insurance sector in India is budding at a rapid rate all through years after the Insurance Regulatory and Development Authority (IRDA).

Approach: IRDA is an act that came into existence in 1999, intending to protect and shield the interests of all policyholders in India. It additionally contributes to commercial development and work. In the post advancement period, it has opened to the private players. With numerous players in the business, the insurance administrative and improvement expert accompanied inventive and helpful rules for the two items and administrations. Innovation and speculation learning was the way to progress in the insurance sector.

Methodology: The theme of this paper is descriptive, and researchers used an in-depth analysis of the growth and development of the Indian insurance sector.

Findings: The results based on secondary data as well as various reports authenticated by IRDA witnesses that not just it is difficult to change over from conventional to unit connected items, yet besides, it is a test to keep the productivity. Client inclination, hardened rivalry, and administrative control are real difficulties for this area of insurance in India. Numerous enterprises are entering in the Life and General insurance sectors in India. This paper examines the difficulties that the insurance business is looking in India.

Research Limitations/Implications: Results could have been more accurate to study the growth and development of an insurance sector in India if some time series data analysis done. Hence this contributes significant research limitations and leaves further scope for research in this sector.

Originality/ Value: The entire study is based on a thorough analysis of various authenticated reports from financial institutions duly regulated and governed by IRDA.

JEL Classification: G00, G001 \& G22,
\end{abstract}

Keywords: Insurance, Regulator, Life insurance, Developments, IRDA

Introduction:-

The growth of the insurance industry is associated with the overall growth if sector, trade, and commerce. The insurance industry helps the advancement procedure of an economy. Fundamentally, the insurance industry goes about as a facilitator of reserve funds, budgetary middle person, an advertiser of venture action, a stabilizer of money related market, chance administrator, and an operator to dispense capital assets proficiently. In spite of the fact insurance business developed quickly in the modern nations, its development in creating societies has neither palatable nor couple with the development of different areas of the economy. The moderate growth of insurance benefits in producing nations requires a top to bottom investigation of the nature and example of the advancement of these administrations.

Approaches sought after to build up the insurance business and requirements thereof additionally require an exhaustive examination. Regardless of the way that general insurance administrations began in India around 150 years prior, their development has been late, too reflected by its low insurance infiltration and thickness. A few components are in charge of this situation, the head being the restraining infrastructure status of the business till as of late. Association structure is the wellspring of the cleverest, planned, and possibly most ruinous sort of progress obstruction. The procedure of advancement and globalization of the Indian economy began in the right sincere in the mid-1990s.

The market component was the spurring factor necessary for the new financial arrangement. In consonance with the new monetary strategy, the insurance segment was opened up for the private sector in 1999. The original aggressive condition is relied upon to profit the clients, business, and the economy on the loose. The privatization and advancement move in India isn't just following the change of the economy, incorporating different parts in the budgetary administrations' industry, yet additionally per the administration's endeavors to meet universal accepted procedures in insurance controls and supervision. 


\section{Dr. Ashfaque Ahmed et.al/International Labor Migration: Employment, Costs and Income of Export Labors in Yen Khe Commune, Thanh Ba District, Phu Tho Province, Vietnam}

\section{Contemporary Challenges in Insurance}

As of late changes in the saving money part and the share trading system made another period in the insurance sector. Not just includes the earth inside which the insurance business experiences an ocean change, yet it additionally went with changes inside the market itself. With the developing mindfulness among buyers, most huge changes inside the company require progress in the example of appropriation and the advancements of new types of security. The insurance showcase in India has grabbed incredibly amazing prospects as India supplied with the enormous undiscovered market. The substance of Life Insurance in India is evolving. However, with the progressions come a large group of difficulties.

The sound players with a long haul vision and a vigorous business procedure alone can yield an effect in the business - interests. Regardless of its abounding one billion populaces, India still has a low insurance infiltration of 1.95 percent. It is an un-facilitated marvel in India that out of sparing rate of 25 percent under 5 percent spent on insurance. The confederation of Indian Industry's (CII) master gather on insurance has assessed the total coverage advertise at a moderate figure of Rs. 188700.00 crores by 2009 - 2010. The life premiums are said to contact Rs. 145000.00 crores by that year, which establishes a 76.8 percent of the total insurance advertise. The non-life dividends are reported to contact Rs. 38600.00 crores, which comprise 20.4 percent of the entire insurance showcase. Individual line insurance is relied upon to reach Rs. 5100.00 crores which frame a 0.02 percent of the total insurance showcase.

It is relevant to take note of that India has achieved the cross streets that insurance agencies can never again work with given limited national limits. Organizations from creating nations must adjust their work culture and their approaches and strategies with those of the taking part in organizations from created countries. This exceptional circumstance currently propels noteworthy changes in territories, for example, their job and their possession design. It likewise includes the subject of overhauling methodologies and arrangements suitable for an open routine.

The insurance policies must be estimated accurately to guarantee from one perspective that the safeguarded don't wind up paying more. Then again, the guarantors have adequate assets with them to spend the cases of the protected when the need emerges. Right evaluating guarantees validity and soundness in insurance advertising. It fortifies the certainty of the protecting open. The terms and states of the insurance offer required are to be standard, uniform, and clear enough a definitive goal of changes is expected to expand insurance thickness and insurance entrance levels by structuring more customized items for clients the two people and foundations. The Data uncovering the Life Insurance Density of India before advancement as against different nations appears in fig 1.

\section{Literature Methodology}

The main aim of this research is to inspect the bearing of liberalization on the Indian life insurance business concerning complete serviceable performance by digging out changing factors and measuring their main sound effects and connections. Researchers have not considered data (primary or Time series) for this specific study.

\section{Literature Review:-}

An enormous and extremely intense body of literature on insurance provides the foundation for this learning as well as study. The various research reviewed in this sector found mainly consists of journals published by the Insurance Institute of India,(III) Federation of Insurance Institute, IRDA, and different insurance magazines. The forecaster has additionally experienced the sites of various insurance agencies and IRDA. An attempt has been made to review past investigations in the zone of privatization quickly, progression, provincial insurance, bank assurance, IRDA, customer and end-user loyalty, insurance inclusion, protection showcasing, and insurance development.

Harold D. Captain Jr (2005) addresses the real issues and concerns identifying with the progression of the insurance markets from a few viewpoints. He sets out the job and significance of government strategy in insurance and calls attention to that the administration intercession in the insurance showcase is fundamental; however, ought to be painstakingly focused on limiting undue obstruction. Additionally talks about the job of outside back up plans with specific accentuation on the worries that have generally been communicated about their careers in national insurance markets of rising economies and calls attention to that such safety net providers ought to be relied upon to assume an essential job in market advancement and improvement. He likewise exhibits an arrangement of standards around which governments should create their direction of insurance and recommends that for having a focused and dissolvable insurance showcase, insurance control ought to have the accompanying qualities to be specific, the exercise for the administration is to make laws and authorize directions that advance progressively straightforward markets upheld by reasonable rivalry. Aggressive insurance advertise serves every nation's advantage. Governments that deny their residents and business such markets reduce buyer decision and thwart national financial advancement.

Kundu (2006), in his article, talks about the different issues in the insurance business after the section of new players. India has a low insurance infiltration of 1.95 percent. The sparing rate in India is 25 percent, yet just less than five percent spent on insurance. The market is seeing a comprehensive exhibit of items from new players. The profile of the customer is additionally evolving. Individuals are searching for incorporated money related arrangements that can offer the strength of return alongside aggregate insurance.

Krishnamurthy (2007) points out that the disaster insurance industry has demonstrated to a high degree attractive outcomes regarding premium pay and new arrangements sold; however, an enormous potential still stays unexploited. Experience recommends that shoppers still support insurance as a sparing apparatus. There is a need to change the impression of Indian customers towards protection, and the circulation channel should exhort and instruct buyers.

Geetanjali Mehlwal (2009), in her article, depicts the insurance showcase as it exists today, its development 


\section{Dr. Ashfaque Ahmed et.al/International Labor Migration: Employment, Costs and Income of Export Labors in Yen Khe Commune, Thanh Ba District, Phu Tho Province, Vietnam}

potential, and the motivating force to private safety net providers from the world over. The investigation proposes that after the progression of the insurance business in March 2000, there has been steady development, and the present potential premium pay of the nation evaluated at $\$ 80$ billion. India viewed as the 6th most significant market on the planet.

In India, 80 percent of the populace stays without disaster insurance, and just 2.5 percent of the nation's insurable populace is right now guaranteed. Even though LIC in the country for quite a while, it didn't tap a significant part rustic market. It mostly focused on gift and cashback strategies. The private insurance has gained considerable ground regardless of the presence of open segment players. Thus there is a decrease in the new premium business of LIC. Between April 2004 and February 2005, LIC's first-year premium dropped by 9.3 percent i.e., 77.87 percent from a piece of the overall industry of 87.22 percent in the preceding year.

The examination calls attention to that the insurance business is developing at the rate of 15-20 percent every year. Insurance entrance had expanded from 2.32 percent in 2000 to 2.88 percent in 2003. In like manner, insurance thickness has grown from Rs. 435.897 in 2000 to Rs.722.092 in 2003. There has been an expansion of 83 percent in the superior gathering amid the three years following the authorization of the IRDA Act. The premium gathered by safety net providers, both life and non-life are assessed to be about Rs.25343.00 billion in the year 20042005. The typical size of disaster insurance cover before privatization, which was around Rs.50000.00, has now been ascended to Rs.80000.00. Insurance agencies are making new interests in data innovation. Today there are interchange channels like bancassurance, intermediaries, corporate specialists, and direct promoting through the web.

Strongpoint Inc. (2019) led an investigation on rustic insurance showcase. The dominant part of the respondents could name the kinds of strategy yet couldn't review the original name of the arrangement. More substantial part obtained cashback arrangements, and the infiltration of entire life strategies was low. An aggregate guaranteed of under Rs.50000.00 represented the more significant part of the provisions taken. A large number additionally received a higher esteem strategy of up to Rs. 100000.00 . There was much closeness between the approach obtained by respondents and the arrangement prescribed by the specialists, recommending that the operators practice an extraordinary impact in the determination of insurance items. It discovered that insurance agencies need to make mindfulness about security and investment funds engaged with insurance and build up the felt-require among these potential clients.

Shobhit and Sanjay Shukla (2011) directed an examination in Lucknow city and its connecting provincial regions to uncover the purposes behind the disappointment of insurance players of the private sector in achieving a critical offer in the country advertise. The investigation discovered that there is a noteworthy contrast in the goals and desires among rustic and urban policyholders. Country populace demonstrated high inclination towards low premium and most hazard inclusion. In-country regions, private players have not made much progress. The private players have not possessed the capacity to give strategies favored by rustic individuals. In urban territories, for the preservationist purchasers, insurance is an expense sparing gadget. In urban regions, buyers having a place with the center pay aggregate lean toward arrangements of open sector players and just high pay bunch favored private part players. The examination likewise uncovered that in urban regions, the proficient client benefit helped the market infiltration by individual players.

Jawaharlal and Pareek (2012) have investigated the requirement for rendering a proficient client benefit in the extra security part. It discovered that at the season of case settlement, operators and agents did not focus on conveying quality client administrations. The absence of instruction and preparing middle people were the significant limitations in giving quality administration. It suggested that the organizations should keep a robust data innovation framework to help the two clients and their middle people. The survey of accessible writing demonstrates that even though there are various examinations and general portrayals about the diverse parts of the insurance sector, there is no explicit investigation identifying with the effect of changes in the insurance business in India. To a specific degree, this examination will fill this hole.

\section{Literature GAP}

While reviewing the literature on the bearing of liberalization on the Indian life insurance industry since 1999, we find that very few studies have conducted to analyze the effect of liberalization by removing change factors encouraged by liberalization. The demeanor of liberalization has been perceived in terms of numerous dimensions, such as the development of distribution channels, technology development, increased penetration, innovative products, and densities, improved service quality, technological advancement, growing employment opportunities, increased productivity, so on and so forth.

\section{History of Insurance in India:-}

The insurance saga is perhaps as old as the tale of humankind. A similar intuition that prompts present-day representatives today to anchor themselves against misfortune and calamity existed in crude men moreover. They also tried to turn away the malicious outcomes of flame and surge and death toll and were eager to make a type of forfeit to accomplish security. Even though the idea of insurance is, to a great extent, an improvement of the ongoing past, especially after the mechanical period recent hundreds of years - yet its beginnings go back right around 6000 years.

Assurance from vulnerability and misfortune has been an essential objective of people and organizations since forever. Insuring against these dangers is the thing that insurance is all about. It began almost 4,500 years prior, in the antiquated place where there is Babylonia, where dealers used to manage the danger of the troop exchange by giving advances that must be later reimbursed with intrigue when the merchandise arrived securely. Disaster insurance came to fruition somewhat than in antiquated Rome, where internment clubs were shaped to cover the burial service 


\section{Dr. Ashfaque Ahmed et.al/International Labor Migration: Employment, Costs and Income of Export Labors in Yen Khe Commune, Thanh Ba District, Phu Tho Province, Vietnam}

costs of its individuals, and additionally help survivors fiscally.

The sort of insurance we see today owes its foundations to the seventeenth century to Lloyd's of London, of England. Lloyd's Coffee House was where shippers, deliver proprietors, and guarantors met to examine and execute business bargains. Insurance moved to America in the year 1735, and the first extra security approach for the overall population in the United States issued in Philadelphia on May 22, 1761. At that point, open risk insurance showed up during the $1880 \mathrm{~s}$ and picked up significance and acknowledgment. Amid the nineteenth century, numerous social orders were established to guarantee the life and strength of their individuals.

The insurance business advanced in India in the eighteenth century. Life coverage business appeared in the year 1818 with the foundation of the Oriental Life Insurance Company in Calcutta. Bombay Mutual Assurance Society Ltd. framed in the year 1870, The Bharat Life Insurance Company in 1896, and the Empire Life Insurance of India in 1897. Following this; the Hindustan Co-agent Life Insurance shaped in Calcutta, the United Life Insurance in Madras, the Bombay Life Insurance in Bombay, the National Life Insurance in Calcutta, the Jupiter Life Insurance in Bombay and the Lakshmi Insurance in New Delhi.

Consistently 1956, when the Life Insurance business nationalized, and Life Insurance Corporation of India (LIC) framed on first September 1956, there were 170 organizations and 75 provident store social orders executing disaster insurance business in India. Later on, after the change to the applicable laws in 1999, the LIC did not have the restrictive benefit of doing new security business in India. As of now, something like 24 life safety net providers is working in the market (according to IRDA Report, Nov 2012).

The historical backdrop of insurance in India profoundly established. Since the most particular occasions, coverage has completed in some frames or other. Insurance in India has created after some time and has taken thoughts from different nations - England correctly.

\section{The Life Insurance Industry Profile in India:-}

Until the early 20th century, the Indian disaster insurance industry was totally in the hands of LIC. During the 1950s, the industry had nationalized to expand the infiltration of insurance in the nation and to make it accessible to less favored sections of society. Yet, even following 40 years of nationalization, just $25 \%$ of the insurable populace was secured under insurance.

There was one of the real explanations behind opening up the sector - to enable private players to move in the direction of broadening the span and inclusion of insurance everywhere throughout the nation. India's fast rate of financial development over the previous decade has been one of the more considerable advancements in the worldwide economy.

This development has its underlying foundations in the presentation of financial progression in the mid-1990s, which has enabled India to abuse its commercial potential and raise the populace's way of life. Insurance has an urgent job in this procedure. Medical coverage and benefits frameworks are principal to securing people against the risks of life, and India, as the second most crowded country on the planet, offers tremendous potential for that sort of cover. Besides, fire and obligation insurance is essential for companies to monitor speculation dangers and framework ventures.

Private insurance frameworks supplement government managed savings frameworks and included an incentive by coordinating danger with cost. Specific hazard valuing is a standout amongst the most useful assets for setting the correct impetuses for the designation of assets, a component that is vital to a quick creating nation like India. Primarily of its business, insurance firmly identified with sparing and contributing. Disaster insurance, subsidized annuity frameworks and non-extra security will amass large measures of capital after some time, which can be put profitably in the economy.

In created nations (re), back up plans regularly claim over $25 \%$ of the capital markets. The shared reliance on insurance and capital markets can assume a fantastic job in diverting assets and speculation aptitude to help the improvement of the Indian economy.

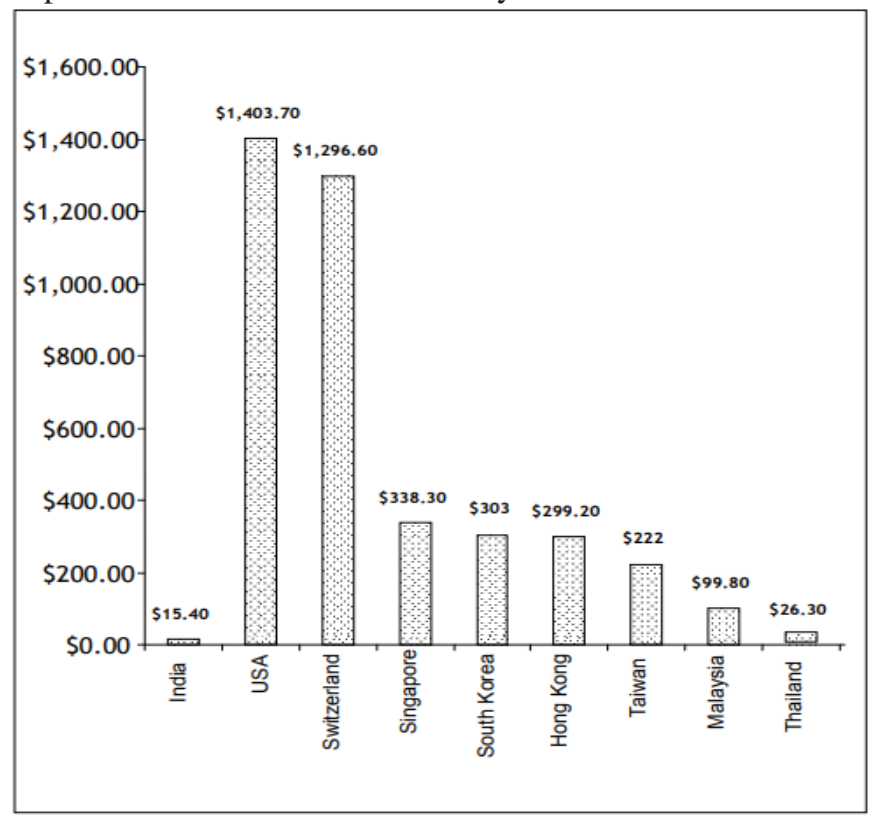

Fig 1: Life Insurance Density of Various Countries (Before Liberalization Privatization and Globalization)

A grouping of many factors underpins added strong escalation in this market, including sound financially viable fundamentals, rising household wealth and a further improvement in the regulatory framework. The insurance business in India has progressed significantly since business was firmly managed and packed in the hands of a couple of open sector back up plans. Following the entry of the Insurance Regulatory and Development Authority Act in 1999, India relinquished open segment selectiveness in the insurance business for market-driven rivalry. This move has achieved real changes to the business. 


\section{Dr. Ashfaque Ahmed et.al/International Labor Migration: Employment, Costs and Income of Export Labors in Yen Khe Commune, Thanh Ba District, Phu Tho Province, Vietnam}

The initiation of another period of insurance advancement has seen the section of universal guarantors, the expansion of creative items and conveyance channels, and the raising of supervisory gauges.

By mid-2004, the quantity of safety net providers in India had been expanded by the passage of new private segment players to an aggregate of 20 , up from five preceding progression. A scope of new items had been propelled to take into account diverse fragments of the market, while different channels including the Internet and bank offices enhanced customary specialists.

These advancements were instrumental in pushing business development, in genuine terms, of $19 \%$ in life premiums and $11.1 \%$ in non-life premiums somewhere in the range of 1999 and 2010. There are valid justifications to expect that the development force can be continued. Specifically, there is tremendous undiscovered potential in different sections of the market.

While the country is intensely presented to regular calamities, insurance to relieve the negative budgetary results of these unfriendly occasions is immature. The equivalent is valid for both benefits and medical coverage, where back up plans can assume a basic job in crossing over interest and supply holes. Real changes in both national monetary arrangements and insurance directions will feature the possibilities of these sections going ahead.

\section{Recent Developments in The Insurance Industry:- Growth of Life Insurance Business in India: In the life insurance business, India ranked 9th among the 156 countries, for which Swiss Re publishes data. Amid 2011- 12 , the assessed extra security premium in India developed by 4.2 percent (expansion balanced). Nonetheless, amid a similar period, the worldwide disaster insurance premium extended by 3.2 percent. The offer of Indian new security areas in the global market was 2.69 percent amid 2012, as against 2.45 percent in 2011 .}

Significance of Agent's Training: The future achievement of the new security calling depends, most importantly, upon the learning and uprightness of the general populations who exhort clients - and are their first and most imperative purpose of contact. At the IRDA, the controllers will probably observe that life guarantors are progressively ready to pull in, persuade, and hold extraordinary individuals focused on receiving a 'needs-based' way to deal with budgetary counsel.

Specialist's Qualification: Keeping the present market needs, the IRDA led an exhaustive audit of the current extra security operator authorizing capability. It was chosen to use the skill of Chartered Insurance Institute (CII), London, in improving the current prospectus of IC-33 "Pre-enlistment capability for life coverage operators" of the Insurance Institute of India (III). All the key partners cooperated to understand this objective. The IC-33 schedule has amended. The preparation in the updated prospectus has initiated from first October 2011. The new course book and the reexamined capability that specialists will presently utilize is an indispensable piece of the Authority's system. IRDA has built up a schedule that is trying in its degree and profundity. It doesn't just urge specialists to retain statistical data points, yet additionally tests their comprehension of learning, and capacity to apply it in a wide variety of down to earth genuine circumstances.

Need Analysis: This is another activity distinguished by IRDA as a stage in controlling guidance incorrectly and misselling. The thought is to expect back up plans to have Prospect Product Matrix that will coordinate an item with the prerequisite, because of the Needs Analysis did.

The input of the partners on the activity has gotten, and draft rules are under readiness. Regulations identifying with separation advertising have been issued by IRDA, which deliver difficulties identifying with mis-moving utilizing separation promoting mode, an aftermath of the headway in innovation. The advantages of having new and quicker channels must be purchased, the escape clauses made by them require stopping, and this is accurately what the rules went-for.

Miniaturized scale Insurance: the IRDA issued MicroInsurance rules in 2005. Miniaturized scale insurance items give insurance security to individuals in lower pay gatherings, for example, self-improvement gathering (SHG) individuals, agriculturists, rickshaw pullers, and others against the dangers that they and their benefits presented-to. The premiums for these items might be as low as 15 and gathered on a week after week premise. The base disaster insurance cover determined by the Regulator for this class is 5,000 , and the most extreme protection that can give is 50,000 . Individuals who work in horticulture and unified exercises presented to the dangers of nature, so they require insurance against risks like rainstorm disappointment, surges, etc. That is the place where smaller scale insurance can act as a hero.

\section{Conclusion:-}

The insurance industry in India had come a long way since business was tightly regulated and concentrated in the hands of a few public sector insurers. Following the entry of the Insurance Regulatory and Development Authority Act in 1999, India deserted open area selectiveness in the insurance business for market-driven rivalry.

This move has realized significant changes to the business. Until the mid 21st century, the Indian life coverage industry was totally in the hands of LIC. During the 1950s, the sector nationalized to expand the entrance of insurance in the nation and to make it accessible to less particular portions of society. Be that as it may, even following 40 years of nationalization, just $25 \%$ of the insurable populace secured under insurance.

That was one of the real explanations behind opening up the area - to enable private players to progress in the direction of expanding the scope and inclusion of insurance everywhere throughout the nation. Commonly of its business, protection firmly identified with sparing and contributing.

Life coverage supported benefits frameworks, and non-extra security will amass large measures of capital after some time, which can be put profitably in the economy. 


\section{Further Scope of Research:-}

India, since the IRDA act 1999, witness tremendous growth and opportunities in India in both life and non-life insurance sectors.

We researchers went through many research papers and after such an intense literature studies we noticed that during 2017-18, the gross premium collection in life and non-life insurance sector was more than INR 5.53 trillion, which is vast and also untapped potential of insurance is found in both industries, hence Indian insurance industry has enormous scope for researchers for further study and research.

\section{REFERENCES:-}

1. Alhassan, R. K., Nketiah-Amponsah, E., \& Arhinful, D. K. (2016). A review of the National Health Insurance Scheme in Ghana: what are the sustainability threats and prospects?. PloS one, 11(11), e0165151.

2. Bajaj Allianz Life Insurance, Financial Consultants Training Manual.

3. Bharti-Axa Life Insurance Company Ltd., Life Advisor Training Guide.

4. Bhende, M. J. (2012). Agricultural insurance in India: Problems and prospects (No. id: 4840).

5. Black, Kenneth Jr ; and Harold D. Skipper Jr: "Life Insurance", 13th , Prentice hall 2000.

6. Christianson, J. B., Parente, S. T., \& Taylor, R. (2002). Defined-contribution health insurance products: Development and prospects. Health Affairs, 21(1), 4964.

7. Dr. Sadhak H, 2009, Life Insurance In India, Opportunities, Challenges and Strategic Perspective, 1st ed. Sage Books Publication .New Delhi.

8. Dr. Shashidharan Kutty: "Life Insurance as a Financial Product", Unpublished PhD Thesis, National Insurance Academy, 2003.

9. Dr. Shashidharan Kutty: "Managing Life Insurance", Prentice Hall, 2008.

10. Faisal, S. M., \& Khan, A. K. (2019). Islamic banking: concept, challenges and proposed solution. Asian Journal of Multidimensional Research, 8(2), 187-194, 2278-4853, DOI: 10.5958/2278-4853.2019.00046.6

11. Faisal, S. M., \& Omar Abdullah Al Aboud, J. (2017). Sharp index model and its utility in portfolio optimization and allocation of funds in stocks. International Journal of Economic, Commerce and Management, 5(1).

12. Faisal, S. M., Al-Aboud, O., \& Majarashi, M. A. Valuation of Currency and Its Impact on Investment: A Study in the Context of Many Confounding Factors.

13. Geetanjali Mehlwal, (2009), "The Face of the Insurance Industry in India", Insurance Chronicle, iupindia.in/106/IC_The_Face_Insurance_Industry_57.ht $\mathrm{ml}$

14. Hellmuth, M. E., Osgood, D. E., Hess, U., Moorhead, A., \& Bhojwani, H. (2009). Index insurance and climate risk: Prospects for development and disaster management. International Research Institute for Climate and Society (IRI).

15. http://shodhganga.inflibnet.ac.in/bitstream/10603/25915 /11/11_chapter\%202.pdf

16. http://www.iii.com

17. Insurance Institute of India.
18. Insurance Institute of India. Annual Reports, 2005 to 2011.

19. Insurance journal published by Insurance Institute of India (III).

20. Insurance Regulatory Development Authority. http://www.irdaindia.org

21. Jawaharlal, U. and Pareek, N. (2012), "Customer Service in Life Insurance”, Insurance Chronicle, IV(3), pp. 43-49

22. K, Faisal, (2018), "Role and Significance of FDI (Outward) in Indian perspective An Analysis: Post Demonetization Period", J Account Mark 7: 276. doi: 10.4172/2168-9601.1000276

23. Khan and Faisal, (2019), "A study for similarities between Islamic practices vis-a-vis accounting practices", Asian Journal of Science and Technology, 10, (04), 9592-9597.

24. Khan, Aboud, 2018, “An Empirical Study of Technological Innovations in the Field of Accounting - Boon or Bane", Business and Management Studies, RedFame, 4(1) : 51 - 58, DOI: https://doi.org/10.11114/bms.v4i1.3057

25. Khan, Ahmad, (2019), "Impact of Demonetization on Outwards Foreign Direct Investment of India Special Reference to Asian Countries" SUMEDHA Journal of Management, Vol 8, No 1, PP (23-42), 2322-0449

26. Krishnamurthy et. al. (2007), Insurance Industry in India: Structure, Performance and Future Challenges, Vikalpa, Iima Volume 30, No. 3, Pg No. 93 - 95.

27. Kundu Subhash C., (2006), "HRM Practices in Insurance Companies: A Study of Indian and Multinational Companies" Managing Global Transitions, 7(2):191-215, 1854-6935

28. Mishra Kailash Chandra and Simita Mishra, 2005, The Game is Changing - Insurance Reloaded. 1st ed. The ICFAI University Press, Hyderabad. pp 205 - 215.

29. Mohammad, Khalid, (2019), "Depreciation of Indian Currency in the Current Economic Scenario", International Journal of Economic Research, Volume 16, 0972-9380

30. Mohammed, A. H., \& Mukhtar, S. (2012). The prospects of micro-insurance in the rural areas of Nigeria. European Scientific Journal, ESJ, 8(3).

31. Murisa, T., \& Chikweche, T. (2013). Entrepreunership And Micro-Finance In Extreme Poverty Circumstances-Challenges And Prospects: The Case Of Zimbabwe. Journal of Developmental Entrepreneurship, 18(01), 1350001.

32. Nissenson, A. R., \& Rettig, R. A. (1999). Medicare's End-Stage Renal Disease Program: Current Status And Future Prospects: The nation's only near-universal health insurance entitlement faces critical challenges in the next few years. Health Affairs, 18(1), 161-179.

33. Omar, A (2018) " Foreign Direct Investment (Influx) from different nations and its impact on Economic Development in India: - A detailed study in Service sector and its contribution in overall economic development". International Journal of Scientific and Research Publications, Volume 8, ISSN 2250-3153, DOI: 10.29322/IJSRP.8.5.2018.p7710

34. Omar, A. (2017), "An Investigation of Indian Security Market, the Viewpoint Of FMCG Companies Who Voyage From Good To Great, International Journal of 
Dr. Ashfaque Ahmed et.al/International Labor Migration: Employment, Costs and Income of Export Labors in Yen Khe Commune, Thanh Ba District, Phu Tho Province, Vietnam

Economics, Commerce and Management, United Kingdom, 1033 - 1046.

35. Shobhit and Shukla, Sanjay (2004), An Empirical Study and Analysis of Failure of Private Insurance Players in Rural Areas, Insurance Chronicle, pp.56-62

36. Singh Inderjit, Katyal Rakesh and Arora Sanjay, 2006, Insurance Principles and Practice. 3rd ed. Kalyani Publishers, Ludhiana.

37. Strongpoint Inc. (2019), "Capitalising on retail megatrends" Equity Research, 1-49.

38. Syed Akmal et al., (2019), "Role and Significance of Crm in View of Commercial Banking Sector - A Study in the Context of Saudi Arabia”, International Journal of Scientific Research and Reviews, 8(1), 3002-3019 